\title{
EFFECTIVENESS OF USE OF PMRI APPROACH (REALISTIC MATH EDUCATION IN INDONESIA) ON RESULTS OF LEARNING MATHEMATICS STUDENTS IN SMP MUHAMMADIYAH 2 KALASAN
}

\author{
Tri Apualinayatia ${ }^{a}$, Sumargiyani ${ }^{\mathrm{b}}$ \\ Program Studi Pendidikan Matematika Universitas Ahmad Dahlan \\ Jalan Ring Road Selatan, Tamanan, Banguntapan, Bantul Yogyakarta \\ a tri.apualinayati@gmail.com, ${ }^{\mathbf{b}}$ sumargiyani04@yahoo.com
}

\begin{abstract}
This research was conducted on the grounds that there were still many students who were less active and initiative in making decisions to solve problems because students only copied from the teacher's example and waited for the teacher's instructions to solve the problems. This study aims to determine the effectiveness of the use of the PMRI Approach (Indonesian Realistic Mathematics Education) Against Mathematics Learning Outcomes of Class VIII Students of SMP Muhammadiyah 2 Kalasan Sleman Regency Even Semester Academic Year 2015/2016. The research design uses PosttestOnly Control Design. The population in this research is the eighth-grade students of SMP Muhammadiyah 2 Kalasan. The research sample was taken using a random sampling technique obtained by class VIII D as an experimental class and VIII B as a control class. Data collection is done by the test method. The instrument testing used validity tests, different power tests, and reliability tests. Data analysis techniques using analysis prerequisite tests include normality test with Chi-Square formula, homogeneity test with Bartlett test, and hypothesis testing with t-test. Based on calculations of the significant level $\alpha=5 \%$ and 67 degrees of freedom could be concluded that: (1) there were different result of Mathematics study between the students who used the learning of PMRI approach and the students who used traditional learning approach. This case showed from the result of the first hypothesis test is $t_{\text {count }}=2,199>t_{\text {table }}=1,996$. (2) learning by using the PMRI approach more effective than using a traditional learning approach. This case showed from the result of the second hypothesis test is $t_{\text {count }}=2,199>t_{\text {table }}=1,668$.
\end{abstract}

Keyword: Effectiveness, Result Study of Mathematics, PMRI (Indonesian Realistic Mathematics Education) Approach

\section{INTRODUCTION}

The development and progress of science that occurs in the life of society, nation, and state in Indonesia and even the world is not free from the influence of global changes that occur at this time. This development also triggered the rapid development of technology causing various social symptoms and obstacles in the community. This encourages people to do things that are more creative and innovative. Progress in each field also makes people motivated to always excel and compete positively, including education. Therefore, it is necessary to improve the national education system. According to the Law of the Republic of Indonesia No. 20 of 2003 concerning National Education System (Sisdiknas) Chapter I article 1 namely: Education is a conscious and planned effort to create an atmosphere of learning and learning process so that students actively develop their potential to have religious-spiritual strength, self-control, personality, intelligence, noble character, and the skills needed by himself, the community, nation, and state. Education in schools covers a variety of subjects, one of which is mathematics. Mathematics is a subject taught at each level of education, from basic education to tertiary education. One learning approach that emphasizes the significance of science is the Realistic Mathematics Education originating from the Netherlands since the 1970s. In Indonesia Realistic Mathematic Education (RME) is known as Indonesian Realistic Mathematics Education (PMRI) since 2001. Indonesian Realistic Mathematics Education is a learning process not just a transfer of knowledge from teacher to student. In PMRI the role of a teacher is emphasized as a facilitator in learning. The teacher facilitates students by guiding students to express their ideas to formulate their own mathematical concepts. PMRI is learning related to real things in the form of mathematical problems so 
students can understand mathematical problems that are often experienced in daily life, and can solve problems in math problems.

Based on the results of observations on class VIII students who have been held at SMP Muhammadiyah 2 Kalasan on October 30, 2015, mathematics learning is still dominated or centered on the teacher as a learning resource. Learning using conventional learning or familiarly called the Traditional learning approach. In their learning activities, students are still less active and initiative in making the right decisions and in solving problems because students only imitate the teacher's example and wait for the teacher's command to solve the problems. Students are also still poorly trained in constructing and discovering their own concepts and formulas. As a result when the teacher gives examples of questions that are different from the example of the previous problem the students become confused and feel difficulty in working on the problem. Students also still think that mathematics is difficult so there are some students who are not active and do not pay attention to the teacher when the teacher is explaining in front. Students' ability to learn mathematics can be measured through mathematics learning outcomes. Good or bad quality of mathematics education is also seen in student learning outcomes. In this case, student learning outcomes in the form of the 2015/2016 Even Semester Midterm Exam indicate that it is still low because there are many students who have not reached the Minimum Mastery Criteria (KKM) of 75. This can be seen in Table 1 which shows the average mathematical grade VIII students of SMP Muhammadiyah 2 Kalasan follows:

Table 1. Results of the Midterm Even Semester Subjects for Mathematics Class VIII SMP

Muhammadiyah 2 Kalasan Academic Year 2015/20116

\begin{tabular}{|c|c|c|c|c|c|}
\hline \multirow{2}{*}{ Value } & \multicolumn{5}{|c|}{ Class VIII } \\
\cline { 2 - 6 } & A & B & C & D & E \\
\hline The highest & 83 & 75 & 58 & 80 & 78 \\
\hline Lowest & 20 & 28 & 23 & 35 & 20 \\
\hline Average & 45,97 & 50,44 & 40,50 & 55,31 & 54,31 \\
\hline KKM & 75 & 75 & 75 & 75 & 75 \\
\hline$\geq$ KKM & 1 & 1 & - & 3 & 2 \\
\hline$<$ KKM & 32 & 33 & 34 & 32 & 34 \\
\hline
\end{tabular}

Source Data: SMP Muhammadiyah 2 Kalasan

Based on an interview with Ms. Lailatul Fu'ah, S.Pd.Si, a mathematics teacher at SMP Muhammadiyah 2 Kalasan on November 9, 2015, there were still many students who were less active in mathematics and considered mathematics difficult so students quickly forgot about concepts and formulas mathematics. Students also only study at school, not repeating lessons they have learned at home, so many students forget the mathematics they have learned at the next meeting. In addition, teaching methods using the PMRI approach have never been applied at SMP Muhammadiyah 2 Kalasan. Therefore, researchers try to apply this PMRI approach which is expected to attract students' interest in mathematics so that it can improve their learning outcomes.

Based on the background, the problem identification and problem boundary that has been described can be formulated as follows:

1. Are there differences in mathematics learning outcomes of students who use the PMRI approach learning with students who use Traditional learning approaches in class VIII students of SMP Muhammadiyah 2 Kalasan Sleman Regency even semester of the 2015/2016 school year?

2. Is learning using the PMRI approach more effective than using the traditional learning approach for students of class VIII SMP Muhammadiyah 2 Kalasan Sleman Regency even semester of the 2015/2016 school year?

Based on the problem formulation above, this study aims to find out the following matters.

1. Knowing whether there are differences in mathematics learning outcomes of students who use PMRI learning approaches and students who use Traditional learning approaches in class VIII 
students of SMP Muhammadiyah 2 Kalasan Sleman Regency even semester of the 2015/2016 academic year.

2. Knowing more effective learning between using PMRI learning approaches by using the traditional learning approach in class VIII students of SMP Muhammadiyah 2 Kalasan Sleman Regency even semester of the academic year 2015/2016.

\section{METHODS}

This type of research is experimental research. "Experimental research is research conducted by studying something that is held. In other words, in experimental research there are treatments from researchers and their impact is measured "(Suparman, 2015: 1). In this study using the posttest-only control design. In this design there are two groups, each randomly chosen (R). The group that was given treatment was called the experimental class while the group that was not treated was called the control class. The design of this study can be seen in Table 2 .

Table 2. Posttest-only control design research design

Information:

\begin{tabular}{|c|c|c|c|}
\hline & Group & Treatment & Postest \\
\hline$(\mathrm{R})$ & $\mathrm{A}$ & $\mathrm{X}$ & $\mathrm{O}_{2}$ \\
\hline$(\mathrm{R})$ & $\mathrm{B}$ & & $\mathrm{O}_{4}$ \\
\hline
\end{tabular}

R : Random

A: $\quad$ Experiment class

B : Control Class

$\mathrm{X} \quad$ : There is a treatment using learning PMRI approach

$\mathrm{O}_{2} \quad$ : Test results for learning outcomes by using learning PMRI approach

$\mathrm{O}_{4} \quad$ : Test results for learning outcomes by using traditional learning approach (Sugiyono, 2015: 76)

The table provides an overview of the steps of this experimental research, namely:

1. Before giving the treatment the researcher analyzed the initial ability by using the initial test (UTS score).

2. The researcher divided the subject into two classes, namely the experimental class and the control class taken randomly.

3. The experimental class was treated using the PMRI learning approach and the control class used the Traditional learning approach.

After each class is given a mathematics learning achievement test (posttest).

This research was conducted at SMP Muhammadiyah 2 Kalasan, Sleman Regency. When the research was conducted in the even semester of the academic year 2015/2016 on the subject of the pyramid. All VIII grade students of SMP Muhammadiyah 2 Kalasan Sleman Regency 2015/2016 Academic Year totaling 172 students. The research sample was carried out by random sampling of the class by lottery to determine which classes would be given learning by using the PMRI approach and the traditional learning approach. The researcher took samples of class VIII D with 35 students as the experimental class, class VIII B with 34 students as controls. Data collection techniques used are the method of documentation and test methods. The documentation used in the form of the results of observations of mathematics learning activities of students of class VIII SMP Muhammadiyah 2 Kalasan to determine the conditions of learning. While the test in the form of a test of learning outcomes (posttest) is given after receiving treatment with the PMRI approach. The instrument used was the Limas learning achievement test in the form of mathematics learning achievement test questions. Before being tested in the experimental class, so that the test results of the learning outcomes that are arranged do not deviate from the material to be taught, then a grid is made, the test items are tested, and a study of the test items for the mathematics learning outcomes test. After the test instruments are arranged, then tested on the instrument test class, namely class VIII E. After the test questions are tested, the test items are analyzed using validity test using the product-moment correlation 
formula, distinguishing power using the discrimination index formula, and reliability testing using the Kuder Richardson-20 formula (KR-20). The analysis prerequisite test used the normality test with the Chi-Square test and homogeneity test with the Bartlet test. Hypothesis testing used two parties and one party t-test.

\section{RESULTS AND DISCUSSION}

Based on the research that has been carried out obtained data in the form of initial abilities and student mathematics learning outcomes.

\section{Initial Ability}

The initial ability scores were obtained from the results of the Even Semester Midterms Grade VIII D and VIII B grades at SMP Muhammadiyah 2 Kalasan Sleman Regency and obtained the initial mathematical ability scores as produced in Table 3

Table 3. Summary Descriptions of Initial Ability Values

\begin{tabular}{|l|c|c|}
\hline \multicolumn{1}{|c|}{ Class } & $\begin{array}{c}\text { Experimentation } \\
\text { Class (VIII D) }\end{array}$ & $\begin{array}{c}\text { Control class } \\
\text { (VIII B) }\end{array}$ \\
\hline The highest score & 80 & 75 \\
\hline Lowest Value & 35 & 28 \\
\hline Average & 55,3 & 50,4 \\
\hline Standard Deviation & 12,98 & 11,63 \\
\hline Variance & 168,55 & 135,31 \\
\hline Lots of Data & 35 & 34 \\
\hline
\end{tabular}

The normality test aims to determine whether the initial ability of the experimental class (VIII D) and the control class (VIII B) is normally distributed or not. A summary of the results of the initial ability normality test is presented in Table 4 .

Table 4. Summary of the Normality Test Results Initial Capability

\begin{tabular}{|l|c|c|}
\hline \multicolumn{1}{|c|}{ Variable } & $\begin{array}{c}\text { Experimentation } \\
\text { Class (VIII D) }\end{array}$ & $\begin{array}{c}\text { Control class } \\
\text { (VIII B) }\end{array}$ \\
\hline$X_{\text {count }}^{2}$ & 7,900 & 3,258 \\
\hline Significance level $(\alpha)$ & $5 \%$ & $5 \%$ \\
\hline $\mathrm{dk}(\mathrm{k}-1)$ & 4 & 2 \\
\hline$X^{2}$ table & \multicolumn{1}{|c|}{9,488} & 5,991 \\
\hline Testing criteria & $\begin{array}{l}\text { Samples are normally distributed if } \\
X^{2}{ }_{\text {count }} \leq X^{2} \text { table }\end{array}$ \\
\hline Information & NORMAL & NORMAL \\
\hline
\end{tabular}

Based on the calculation of normality test Table 4 experimental class data with a significant level of $5 \%$ and $\mathrm{df}=4$, it can be seen that $\chi_{\text {count }}^{2}<\chi_{\text {table }}^{2}$ which means that the experimental class has normally distributed data. Normality test conducted in the control class with a significant level of $5 \%$ and $\mathrm{df}=2$, it can be seen that $\chi_{\text {count }}^{2}<\chi_{\text {table }}^{2}$ which means that the control class has normally distributed data.

The homogeneity test is done once, which is to test the homogeneity of the experimental class and the control class. The calculation results show that the experimental class and the control class meet the homogeneity requirements, which have the same variance. A summary of the results of the initial homogeneity capability is presented in Table 5 . 
Table 5. Summary of the Homogeneity Test of Initial Ability Values

\begin{tabular}{|l|c|c|}
\hline \multicolumn{1}{|c|}{ Variable } & \multicolumn{1}{c|}{$\begin{array}{c}\text { Experimentation } \\
\text { Class (VIII D) }\end{array}$} & $\begin{array}{c}\text { Control class } \\
\text { (VIII B) }\end{array}$ \\
\hline \multicolumn{1}{|c|}{$S_{i}{ }^{2}$} & 182,692 & 122,678 \\
\hline$X^{2}{ }_{\text {count }}$ & \multicolumn{2}{|c|}{1,317} \\
\hline $\begin{array}{l}\text { Significance level } \\
(\alpha)\end{array}$ & $5 \%$ & $5 \%$ \\
\hline $\mathrm{dk}(\mathrm{n}-1)$ & 34 & 33 \\
\hline$X^{2}{ }_{\text {table }}$ & \multicolumn{2}{|c|}{3,841} \\
\hline Testing criteria & $\begin{array}{l}\text { Samples are normally } \\
X_{\text {count } \leq} X^{2}{ }_{\text {table }}\end{array}$ & distributed if \\
\hline Information & HOMOGENEOUS \\
\hline
\end{tabular}

The test criteria for homogeneity tests are if $\chi_{\text {count }}^{2}<\chi_{\text {table }}^{2}$, hence the variance of the sample is homogeneous. Based on Table 5 above it appears that the value $\chi_{\text {count }}^{2}=1,317$ and $\chi_{\text {table }}^{2}=$ 3,841 , then $\chi_{\text {count }}^{2}<\chi_{\text {table }}^{2}$ at a significant level $\alpha=5 \%$ and $\mathrm{df}=1$, so that the variance of students' initial ability data in the study is homogeneous.

A summary of the results of the two-party hypothesis test of the initial ability scores of the experimental class (VIII D) and the control class (VIII B) can be seen in Table 6.

Table 6. Summary of Results of the Two-Party Hypothesis Test Initial Values

\begin{tabular}{|c|l|}
\hline$t_{\text {count }}$ & $\mathbf{t}_{\text {table }}$ \\
\hline 1,635 & 1,668 \\
\hline
\end{tabular}

Based on Table 6 obtained values $t_{\text {count }}<t_{\text {table }}$, then $\mathrm{H}_{0}$ is accepted which means that there is no difference in the initial ability scores of the experimental class students (VIII D) and the control class (VIII C) Muhammadiyah 2 Middle School Kalasan Sleman Regency in the academic year 2015/2016.

\section{Mathematics Learning Outcomes}

A description of the data of students' mathematics learning outcomes after the experiment is presented in Table 7 .

Table 7. Summary Description of Mathematics Learning Outcomes

\begin{tabular}{|l|c|c|}
\hline \multicolumn{1}{|c|}{ Class } & $\begin{array}{c}\text { Experimentation } \\
\text { Class (VIII D) }\end{array}$ & $\begin{array}{c}\text { Control class } \\
\text { (VIII B) }\end{array}$ \\
\hline The highest score & 94,4 & 88,9 \\
\hline Lowest Value & 50,0 & 44,4 \\
\hline Average & 74,8 & 67,8 \\
\hline Standard Deviation & 13,00 & 12,82 \\
\hline Variance & 169,03 & 164,44 \\
\hline Lots of Data & 35 & 34 \\
\hline
\end{tabular}

The normality test aims to determine whether the value of mathematics learning outcomes of the experimental class (VIII D) and control class (VIII B) is normal or not. A summary of the results of normality scores for students' mathematics learning outcomes is presented in Table 8. 
Table 8. Summary of Normality Test Results for Mathematics Learning Outcomes

\begin{tabular}{|l|c|c|}
\hline \multicolumn{1}{|c|}{ Variable } & $\begin{array}{c}\text { Experimentation } \\
\text { Class (VIII D) }\end{array}$ & $\begin{array}{c}\text { Control class } \\
\text { (VIII B) }\end{array}$ \\
\hline$X_{\text {count }}^{2}$ & 6,609 & 3,464 \\
\hline$X_{\text {stat }}$ & $5 \%$ & $5 \%$ \\
\hline Significance level $(\alpha)$ & 4 & 4 \\
\hline dk $(\mathrm{k}-1)$ & \multicolumn{1}{|c|}{9,488} & 9.488 \\
\hline$X^{2}{ }_{\text {table }}$ & $\begin{array}{l}\text { Samples are normally distributed if } \\
X_{\text {count }}^{2} \leq X^{2} \text { table }\end{array}$ \\
\hline Testing criteria & NORMAL & NORMAL \\
\hline
\end{tabular}

Based on the calculation of normality test Table 8 experimental class data with a significant level of $5 \%$ and $\mathrm{df}=4$, it can be seen that $\chi_{\text {count }}^{2}<\chi_{\text {table }}^{2}$ which means that the experimental class has normally distributed data. Normality test conducted in the control class with a significant level of $5 \%$ and $\mathrm{df}=4$, it can be seen that $\chi_{\text {count }}^{2}<\chi_{\text {table }}^{2}$ which means that the control class has normally distributed data.

The homogeneity test is done once, which is to test the homogeneity of the experimental class and the control class. The calculation results show that the experimental class and the control class meet the homogeneity requirements, which have the same variance. A summary of the results of the initial homogeneity capability is presented in Table 9.

Table 9. Summary of Homogeneity Test Results Mathematics Learning Outcomes

\begin{tabular}{|c|c|c|}
\hline Variable & $\begin{array}{c}\text { Experimentation } \\
\text { Class (VIII D) }\end{array}$ & $\begin{array}{l}\text { Control class } \\
\text { (VIII B) }\end{array}$ \\
\hline$S_{i}{ }^{2}$ & 180,361 & 164,196 \\
\hline$X_{\text {count }}^{2}$ & \multicolumn{2}{|c|}{0,074} \\
\hline$X_{\text {count }}^{2}$ & $5 \%$ & $5 \%$ \\
\hline $\begin{array}{l}\text { Significance level } \\
(\alpha)\end{array}$ & 34 & 33 \\
\hline $\mathrm{dk}(\mathrm{n}-1)$ & 3,841 & 3,841 \\
\hline$X^{2}{ }_{\text {table }}$ & \multicolumn{2}{|c|}{$\begin{array}{l}\text { Samples are normally distributed if } \\
X_{\text {count }}^{2}<X_{\text {tabel }}^{2}\end{array}$} \\
\hline Testing criteria & HOMOGENEOUS & \\
\hline
\end{tabular}

The test criteria for homogeneity tests are if $\chi_{\text {count }}^{2}<\chi_{\text {table }}^{2}$, then the variance of the sample is homogeneous. Based on Table 9 above it appears that the value $\chi_{\text {stat }}^{2}=0,074$ and $\chi_{\text {table }}^{2}=3,841$, then $\chi_{\text {count }}^{2}<\chi_{\text {table }}^{2}$ at a significant level $\alpha=5 \%$ and $\mathrm{df}=1$, so the data variance of students' mathematics learning outcomes in research is homogeneous.

Hypothesis Test of Two Parties Learning Outcomes of Mathematics

$\mathrm{H}_{0}: \mu_{1}=\mu_{2}$

$\mathrm{H}_{1}: \mu_{1} \neq \mu_{2}$

Dengan

$\mathrm{H}_{0}$ : There is no difference in mathematics learning outcomes of students who use PMRI approach learning with students who use Traditional learning approaches in class VIII students of SMP Muhammadiyah 2 Kalasan Sleman Regency even semester of the 2015/2016 academic year.

$\mathrm{H}_{1}$ : There are differences in mathematics learning outcomes of students who use PMRI learning approaches and students who use Traditional learning approaches in class VIII students of SMP Muhammadiyah 2 Kalasan Sleman Regency even semester of the 2015/2016 school year. 
A summary of the results of the two-party hypothesis test on mathematics learning outcomes can be seen in Table 10 .

Table 10. Summary of Hypothesis Test Results of Two Parties Mathematical Learning

Outcomes

\begin{tabular}{|c|c|}
\hline $\boldsymbol{t}_{\text {count }}$ & $\boldsymbol{t}_{\text {table }}$ \\
\hline 2,199 & 1,996 \\
\hline
\end{tabular}

Based on Table 10 obtained values $t_{\text {count }}>t_{\text {table }}$, then $\mathrm{H}_{0}$ is rejected $H_{1}$ is accepted, which means that there is a difference between student learning outcomes in mathematics using the PMRI Approach and students using the Traditional Learning Approach in class VIII even semester of SMP Muhammadiyah 2 Kalasan for the 2015/2016 school year.

One-Party Hypothesis Testing Learning Outcomes of Mathematics

$\mathrm{H}_{0}: \mu_{1}=\mu_{2}$

$\mathrm{H}_{1}: \mu_{1}>\mu_{2}$

With :

$\mathrm{H}_{0}$ : Learning using the PMRI Approach is no more effective than using the Traditional Learning Approach of VIII grade students of SMP Muhammadiyah 2 Kalasan Sleman Regency even semester of the 2015/2016 academic year.

$\mathrm{H}_{1}$ : Learning using the PMRI Approach is more effective than using the Traditional Learning Approach of VIII grade students of SMP Muhammadiyah 2 Kalasan Sleman Regency in the even semester of the 2015/2016 school year.

A summary of the results of the one-party hypothesis test on mathematics learning outcomes can be seen in Table 11 .

Table 11. Summary of Results of One-Party Hypothesis Test Results of Mathematical Learning Outcomes

\begin{tabular}{|c|c|}
\hline $\boldsymbol{t}_{\text {count }}$ & $\boldsymbol{t}_{\text {table }}$ \\
\hline 2,199 & 1,668 \\
\hline
\end{tabular}

Based on Table 11 obtained values $t_{\text {count }}>t_{\text {table }}$, then $\mathrm{H}_{0}$ is rejected $H_{1}$ is accepted, which means that learning using the PMRI Approach is more effective than using the Traditional Learning Approach in class VIII students of SMP Muhammadiyah 2 Kalasan Sleman Regency Academic Year 2015/2016.

\section{CONCLUSION}

Based on the results of research and discussion as outlined in Chapter IV, several research conclusions can be drawn as follows:

1. There are differences in mathematics learning outcomes of students who use PMRI learning approaches and students who use Traditional learning approaches in class VIII students of SMP Muhammadiyah 2 Kalasan Sleman Regency even semester 2015/2016 academic year. This is indicated by the results of the first hypothesis test wherewith a significant level of 5\% and 67 degrees of freedom, the values $t_{\text {count }}=2.199$ and $t_{\text {table }}=1.996$ are obtained, meaning $t_{\text {count }}>$ $t_{\text {table }}$, so $H_{0}$ is rejected, $H_{1}$ is accepted.

2. Learning using the PMRI approach is more effective than using the Traditional learning approach for students of class VIII of SMP Muhammadiyah 2 Kalasan Sleman Regency in the even semester of the academic year 2015/2016. This is indicated by the results of the second hypothesis test wherewith a significant level of 5\% and 67 degrees of freedom, the values $t_{\text {count }}=2.199$ and $t_{\text {table }}$ $=1.668$ are obtained, meaning $t_{\text {count }}>t_{\text {table }}$, so $H_{0}$ is rejected, $H_{1}$ is accepted. 


\section{REFERENCES}

Arikunto, Suharsimi. 2010. Prosedur Penelitian Suatu Pendekatan Praktek (Edisi Revisi 2010). Jakarta: P.T.Rineka Cipta.

Darsono. 2010. Jurnal:PMRI (Pembelajaran Matematika Realistik Indonesia) Suatu Inovasi Dalam Pendidikan Matematika Di Indonesia. https://nazwandi.wordpress.com/2010/06/22/jurnalpmripembelajaran-matematika-realistik-indonesia-suatu-inovasi-dalam-pendidikan-matematika-diindonesia/ (diakses tanggal 31 Maret 2016).

Sugiyono. 2015. Metode Penelitian Kuantitatif, Kualitatif, dan R\&D. Bandung: Alfabeta.

Suherman, Erman, dkk. 2003. Strategi Pembelajaran Matematika Kontemporer. Yogyakarta: Universitas Pendidikan Indonesia.

Sudjana. 2005. Metode Statistik. Bandung: PT Tarsito.

Suparman. 2015. Metodologi Penelitian Pendidikan. Yogyakarta: MIPA UAD Press.

Undang-undang Republik Indonesia No 20 Tahun 2003 Bab 1 Pasal 1 Sistem Pendidikan Nasional. 